\title{
When patrons are patrons: A social-scientific and realistic reading of the parable of the Feast (Lk 14:16b-23)
}

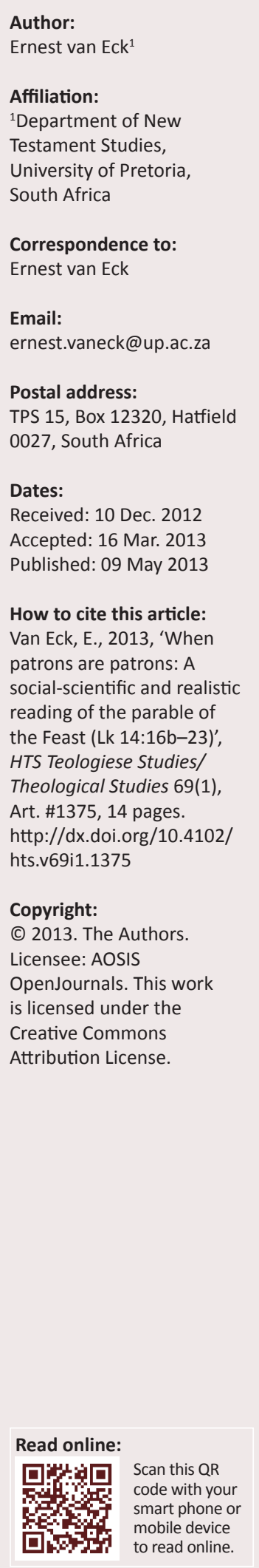

This article presents a social-scientific and realistic interpretation of the parable of the Feast. The characteristics of a pre-industrial city are used to determine the realism of the parable. The social-scientific interpretation of the parable considers meals as ceremonies. The cultural values embedded in meals, namely honour and shame, patronage, reciprocity and purity, receive attention. The social dynamics of invitations in the 1st-century Mediterranean world is used as a lens to understand the invitations as an honour challenge, and the social game of gossip is used to obtain an understanding of the excuses in the parable. The conclusion reached is that the parable turns the world in which it is told upside down. As such, the parable has something to say about the injustices that are a part of the society we live in.

\section{Introductory remarks}

Why, in the parable of the Feast, are the guests invited twice? Who is the host, and who are the invitees? Why do only three of the invitees excuse themselves, but not one of the 'many' invited (Lk 14:16b) show up? And what does it mean when the slave is sent by the host to invite those in the wider streets, squares, narrow streets and alleys (Lk 14:21), as well as those in the roads and country lanes or hedges (Lk 14:23)? These important questions are addressed in this contribution.

The reading of the parable is structured as follows: The history of the interpretation of the parable is given, after which the authenticity of the three extant versions is discussed. Luke's version of the parable is identified as closest to the earliest layer of the historical Jesus and delimited to Luke 14:16a-23 (integrity). After a description of the characteristics of the pre-industrial city and the social dynamics of invitations in the 1st-century Mediterranean world, the article focuses on gossip and meals as ceremonies. Attention is also paid to the cultural values that were embedded in meals in the 1st-century Mediterranean world, namely honour and shame, patronage, reciprocity and purity. A reading of the parable is then offered. Finally, it is argued that the parable most probably dates back to the earliest layer of the historical Jesus-tradition.

\section{History of interpretation}

The history of the interpretation of the parable shows that scholars approach the parable in one of three ways. The parable is interpreted either allegorically or theologically or the parable is read in terms of its Lukan context or the parable is read as an authentic saying of Jesus used by Luke. In the latter case, the redactional activity of Luke is sometimes evoked.

\section{Allegorical and theological interpretations}

The earliest interpretations of the parable of the Feast are the allegorical interpretations of Augustine, Origin, Bede and Aquinas and the historical and literal (theological) interpretations of Luther, Calvin and Maldonatus. Augustine (Sermon LXII, in Schaff 1890) equates the host with Jesus and the invitees with Israel. The first excuse refers to the 'spirit of domination', the five oxen to the senses of the body that cause people to seek earthly things and things of the flesh, and the third excuse refers to the lust of the flesh. The parable calls on believers to do away with the vain and evil excuses of the flesh and come to the Eucharist. Contrary to Augustine, Origin identifies the banquet as the spiritual food of God's mysteries (see Snodgrass 2008:308). In Bede's and Aquinas' interpretation, the streets and alleys of the town (Lk 14:21) and the roads and country lanes (Lk 14:23) represent the teaching and errors of the heathen that have to be brought into (corrected) the church (the dinner party; see Kissinger 1979:40,43). Luther understands the dinner as symbolic of the feast that God prepared through Christ (salvation) with the phrase 'all things are ready' (Lk 14:17) referring to the price that God paid in Christ for all sins (see Hunter 1971:32). For Calvin, the focus of the parable is election. Many are called and hear the word, but only a few 
are chosen because only a few prove their faith by newness of life (see Torrance \& Torrance 1972:105-110). Maldonatus interprets the parable in more or less the same vein as Calvin: Many are called, but only few come - not all who come to the church when called will be saved (see Davie 1888:222-230).

\section{The parable in its Lukan context}

The interpretation of scholars who read the parable in its Lukan context focuses on different aspects of the parable, coming to a plethora of conclusions regarding the crux of the parable. Scholars who focus on the invitations in the parable see salvation history as a key to unlock its meaning. The first invitees are the Jews, and the second and third invitees are the Gentiles. Because the Jews rejected the invitation, the parable is a judgement on Israel as nation (see e.g. Keach 1978:544; Lockyer 1963:276; Schippers 1962:41; Swartley 1997:177; Timmer 1990:57). Hultgren (2000:336-337) differs marginally from these scholars in his interpretation of the invitations but comes to the same salvation-historical conclusion: The first invited are the Jewish aristocracy, the second the lowerclass Jews and the third group the Gentiles. The parable thus teaches that salvation is not only for the Jews (sinners and tax collectors) but that it is also available to the Gentiles (see also Haenchen, in Swartley 1997:188).

A second group of scholars who read the parable in its Lukan context identifies one of Luke's main theological themes in the parable, namely the announcement of the kingdom to the poor. Bruce (1886:32) and Knapp (1920:97-112) were the first scholars to read the parable from this perspective, and they are followed in their interpretation especially by Schottroff (1987:211, 2006:55, 2007:593; see also Perkins 1981:98; Wenham 1989:134; Young 1989:176). Read from this perspective, the parable spells out the Lukan Jesus' attitude towards the poor and teaches that the kingdom is for the hungry. Luke is using the parable to confront the rich of his own community who are avoiding association with poor Christians (Rohrbaugh 1991:142), and he exhorts them, in their abundance, to aid the poor, the common people and the outcasts of society about whom nobody cares.

A third interpretation of the parable focuses on the grace of God as the main emphasis in the parable. The parable is about the mercy, grace and compassion of God, symbolised by the action of the host (see Boice 1983:66; Braun 1995:131; Manson 1951:75; Swartley 1997:189; Trench 1953:24-30).

A fourth group of interpreters' understanding of the thrust of the parable is linked to the emphasis on the grace of God (the host). God's grace implies that all are invited to the feast, an invitation that asks for a decision - the kingdom is present, but only those who come to the feast will partake in it (Hunter 1971:96; Kistemaker 1980:163; Linnemann 1980:91-92; Sanders 1974:260-264). Read in the light of this perspective, the parable teaches that the nature of the kingdom is that it is a gift offered to man, an invitation to enter (Morgan 1953:181). Nobody is excluded from God's kingdom except by his or her own choice. The parable thus urges the hearer to discern the signs of the times and repent before it is too late (Hunter 1971:85).

Some scholars, as a fifth perspective, argue that the Lukan Jesus used the parable of the Feast as a symbol to portray the future eschatological or messianic banquet (Hendrickx 1986:113; Stein 1981:85-86). From this perspective, the parable implies that those who do not accept God's invitation to his dinner (salvation) will be judged (Groenewald 1973:198).

The parable, finally, is read by some as a challenge to the Pharisees to reconsider the exclusion of people they deem impure from the cultic sphere (Arens 1986:452). It calls them, and the reader, into a mission to the impure and the Gentile (Dormeyer, in Swartley 1997:188).

\section{The parable as an authentic saying of the historical Jesus}

Most scholars who read Luke's version of the parable as an authentic saying of the historical Jesus do not differ much in their interpretations from those who read the parable as redactionally used by Luke. In most cases the same themes are identified, namely salvation (Boucher 1981:103), Jesus' attitude towards the poor (Jeremias 1972:64; Kilgallen 2008:82), the need for decision and repentance (Brouwer 1946:94), the eschatological banquet (Bailey 1983:89, 92; Marshall 1978:587; Scott 2001:109-117; Snodgrass 2008:311, 316; Stein 1981:87), the defence of the fact that the gospel is extended to outcasts (the vindication of the good news; Bailey 1983:111; Jeremias 1972:64) and mission (Boucher 1981:103; Perkins 1981:97). For these scholars, the message of the parable in its Lukan context (96 CE) concurs with what Jesus intended when he told the parable in a context around 27-30 CE.

Three approaches to the parable that takes the social and contextual world of the parable in 27-30 CE seriously are that of Crossan, Funk, Hoover and the Jesus Seminar and Rohrbaugh. For Crossan and Funk, Hoover and the Jesus Seminar, the startling element or surprising twist in the parable is the random and open commensality of its meal (Crossan 1991:262), the socially marginal that fill the hall (Funk et al. 1993:353) - an aspect of the parable that makes it a genuine Jesus story (Funk et al. 1993:353). Rohrbaugh's (1991:151-180) reading of the parable identifies the same startling element in the parable. The lens he uses to read the parable, however, differs from that of Crossan and Funk et al. Whereas the latter focus on the social dynamics of meals (as ceremonies) in the 1st-century Mediterranean world, Rohrbaugh reads the parable in terms of its implied preindustrial setting and the pivotal role honour and shame played in the 1st-century Mediterranean world.

Below, the valuable contributions of these three interpretations will inter alia be used to read the parable from a socialscientific perspective in a historical setting of 27-30 CE. The contribution of Rohrbaugh will especially be employed to aid a realistic reading of the parable (verisimilitude). 


\section{Versions and integrity}

\section{Extant versions}

Three extant versions of the parable, namely Luke 14:16b-24, Thomas 64:1-12 and Matthew 22:2-14, have all been edited redactionally; the earliest form of the parable is thus not clear. The same can be said of the parable's origin. Some scholars argue that Matthew and Luke have drawn their respective parables from oral tradition (M and $\mathrm{L}){ }^{1}$ some are of the opinion that both versions stem from $\mathrm{Q}^{2}$ whilst others argue for Thomas as the source of the original parable used by Matthew and Luke (Crossan 1973:72; Fitzmyer 1985:1052; Jeremias 1972:63; Perrin 1967:35). Broadly speaking, the versions of Thomas and Luke are similar whilst Matthew's version differs considerably from the other two versions. Do we have a common source behind all three extant versions? Do the versions in Luke and Matthew stem from two independent oral versions or from $\mathrm{Q}$ ? Does the Thomasine version represent an independent tradition or is Thomas 64:1-12a redacted version of Luke, or even Q? To answer these questions, a closer look is needed at the redactional activity that can be traced in the three versions.

\section{Matthew 22:2-14}

Almost all scholars agree that the Matthean version of the parable is secondary (see e.g. Boucher 1981:103; Brouwer 1946:70; Gundry 1982:433; Hunter 1976:56; Linnemann 1980:93; Perkins 1981:95; Scott 1989:162; Smith 1937:16). Matthew's version of the parable is a conflation of two parables, namely the parable of the Marriage Feast (Mt 22:2-10) and a parable that can be called 'the Visit and Judgement of the King', or the Wedding Garment (Mt 22:11-14; Crossan 1973:69). Matthew uses the first parable as an introduction to the second (Jeremias 1972:67-68) ${ }^{3}$ and has redactionally edited both parables heavily.

The first parable (Mt 22:2-10) has Jerusalem as the setting and changes the $\delta \varepsilon \tilde{\pi} \pi v 0 v$ [dinner] of Luke into a wedding feast that a king prepares for his son. This redactional change enables Matthew to turn the parable into an allegory of the history of salvation: A king (God) prepares a feast for his son (Jesus) and invites (three times) his subjects (Israel) to the feast. The invitees refuse the second invitation of the servants (the prophets), and when they are invited yet again by a greater number of servants (the apostles and missionaries), some pay no attention to the invitation whilst others kill the king's servants. The king is angered and retaliates by destroying the invited guests and their city (Jerusalem). He then invites

1.This position is inter alia supported by Davies and Allison (1997:194), Dodd (1961:95), Drury (1985:125), Gnilka (1993:235), Groenewald (1973:198), Hill (1972:301), Hultgren (2000:335), Kistemaker (1980:164-165), Linnemann (1980:166, n. 2), Luz (1985:233), Plummer (1922:359), Smith (1937:203), Snodgrass (2008:310), Stein (1981:83), Streeter (1930:244), Via (1967:129) and Weiser (1971:59-60).

2.Some of the proponents of this position are Brouwer (1946:171), Boucher (1981:103) Conzelmann (1960:111), Donahue (1988:140), Hagner (1995:627), Hendrickx (1986:131), Hunter (1976:56), Jones (1995:401), Klein (1997:430-437, Manson (1951:129-130), Polag (1979:70), Schippers (1962:41), Schottroff (1987:192), Schulz (1973:391-398), Schottroff (2006:53, 2007:593), Scott (1989:167, 2001:109-117), Trench (1953:24-30) and Weder (1978:178).

3.In Matthew 22:9-11, the king invites people without any preconditions, and then in Matthew $22: 11-13$, he expects all the gathered guests to have wedding garments.
This expectation breaks the logical unity of the parable, indicating that Matthew This expectation breaks the logical unity of the parable, ind
22:11-13 was added to Matthew 22:2-10 (Crossan 1973:69). others (Gentiles) to the feast, and they respond positively and fill the wedding hall (see Crossan 1973:69-70; Funk et al. 1993:352; Funk, Scott \& Butts 1988:43; Perkins 1981:95; Scott 2001:109-117; see also Calvin, in Torrance \& Torrance 1972:105-110).

When one compares Matthew 22:2-10 with the parable of the Tenants (Mt 21:33-44) that immediately precedes it in the Matthean narrative, is it clear that Matthew has redactionally edited the parable of the Marriage Feast to parallel his version of the parable of the Tenants by taking up its theme and phrases. Matthew 22:3-4 parallels Matthew 21:34 and 36 (the sending of the servants), the killing of the servants in Matthew 22:6 is repeated in Matthew 21:35 and the king's retaliation in Matthew 22:7 (the burning of the city of those who declined the invitations - clearly a reference to the destruction of Jerusalem in $70 \mathrm{CE}$ ) parallels Matthew 21:41 (the killing of the tenants of the vineyard - the chief priests and Pharisees). ${ }^{4}$ The destruction of the rebellious in Matthew 22:7 also resonates a similar destruction of the enemies in the parable of the Pounds (Mt 19:27; Snodgrass 2008:307), and the reference to good an evil (Mt 22:10), a reference to the church which Matthew consistently views as mixed, parallels Matthew's interpretation of the parable of the Wheat and Tares (Mt 13:37-43; see Scott 2001:112). Matthew 22:2-10 also picks up themes from other parables in his gospel. The parable of the Marriage Feast is the climax of three parables in Matthew (Mt 21:28-32, 21:33-44 and 22:2-10) that all depict the church as the true Israel (Dillon 1966:1-42; Scott 1989:162-163) and castigates the opponents of Jesus (Hultgren 2000:343). The introduction to the parable

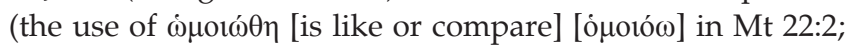
see also Mt 7:24,26), finally, is a typical Matthean feature.

To this allegory, Matthew added the parable of the Visit and Judgement of the King (Mt 22:11-14; Boucher 1981:104; Perkins 1981:98, Snodgrass 2008:300; Via 1967:128-132). The parable of the Visit and Judgement of the King is also heavily allegorised. The parable, firstly, links with the reference to good and bad - Matthew's alternative for Luke's poor, maimed, blind and lame - in the previous parable (Mt 22:10), and serves as a warning to the good and bad that they will be judged (Funk et al. 1988:43; Funk et al. 1993:235; Snodgrass 2008:300). Judgement depends on whether one is properly dressed or not (having a wedding garment). ${ }^{5}$ The wedding garment serves as an allusion 'to Christians who join the community but turn out not to fit and so expelled' (Funk et al. 1988:43) or 'those who do not produce proper fruit' (Scott 2001:112). The reference to the outer darkness in Matthew 22:13, secondly, is typically Matthean (see Mt 8:12; 13:42, 50; 24:13; 24:51; 25:30). Matthew 22:14, thirdly, is either a Matthean invention (Funk et al. 1993:235; Perkins 1981:95) or

4.Without reading the parable of the Tenants, the parable of the Marriage Feast is thus not intelligible (Drury 1985:97-98). Or, as put by Goulder (1974:415): 'The Marriage Feast parable is nothing but a second version of the Wicked Husbandmen, with suitable Christian gloss, and in the Matthean manner' (see also Perkins 1981:95).

5.The reference to not being properly dressed is a typical Matthean theme, namely that 'the Christian community is a mixture of the good and the bad, the deserving and undeserving, who will be sorted out at the judgment' (see the sabotage of the and undeserving, who will be sorted out at the judgment' (see the sabotage of the
weeds - Mt 13:24-30; the allegory of the last judgement - Mt 25:31-46; Funk et al. weeds - Mt 13:24-30; the allegory of this
1993:235; see also Perkins 1981:95). 
an independent logion (Snodgrass 2008:300) that is a textual variant of Matthew 20:16. By adding the second parable, Matthew has transformed the first parable into an outline of the history of salvation, starting with the prophets, then having the Christian missionaries and the fall of Jerusalem and ending with the messianic banquet in the new age and the last judgement (see Boucher 1981:103; Drury 1985:72-73, 78; Jeremias 1972:69).

The themes of the two parables (or one parable, the Wedding Feast) are the result of Matthew's redactional activity. In Matthew, the parable of the Wedding Feast becomes an allegory of Jewish rejection, Christian acceptance and final judgement (Scott 2001:112). Matthew's allegory is alien to Jesus: The parable looks back on the destruction of Jerusalem (Funk et al. 1988:43), and the condoning of violence in Matthew 22:7 - as coming from Jesus - cannot be reconciled with Jesus' stance on violence (see Van Eck 2008:1735-1765). There is, to cite Funk et al. (1993:235), 'very little left of the original parable in Matthew's version. ${ }^{6}$ None of Matthew's themes are part of the Lukan version of the parable. Matthew's version of the parable, above all, destroys verisimilitude (Scott 1989:162). The parable lacks realism, and the parable has been turned into metaphoric theology.

\section{Luke 14:15-24}

Most scholars are of the opinion that Luke's version of the parable also had undergone some editorial modifications. In Luke, the parable of the Feast is part of table talk in the house of a Pharisee (Lk 14:1) that consists of four pericopes which are all introduced either explicitly or implicitly by the giving of and invitation to a meal. In the first pericope (Lk 14:1-6), Jesus is invited to a meal on the Sabbath where Pharisees and the impure - a man suffering from dropsy, falling in the category of the poor, crippled, lame and the blind - are present. The focus of this micro-narrative is the question whether one should heal (accept) or not heal (refuse) someone in need on the Sabbath. The themes of this micronarrative (meals, guests, invitation, acceptance and refusal) set the scene for what is to follow in the macro-narrative. In Luke 14:7-10, the focus is the acceptance or refusal of places of honour at a dinner table (seating arrangements), and Luke 14:12-14 focuses on who one should invite. The main thrust of the latter two micro-narratives is that one should refuse the place of honour at a table and invite those without honour.

This contextual introduction to the parable (most probably a Lukan construction), most scholars argue, has influenced the way in which Luke narrates the parable of the Feast. The parable is, as Scott (1989:169) argues, an example of the counter wisdom of Jesus, explained in Luke 14:1-14. The first invitation in Luke 14:21 parallels Jesus' advice in Luke 14:13 (inviting the poor, crippled, blind and lame), a favourite theme of Luke (see Lk 4:18-19; 7:22; Funk et al. 1993:352;

6.This conclusion is the direct opposite of that of Snodgrass. According to Snodgrass (2008:310), the differences between the Matthean and Lukan versions of the parable are the result of Jesus telling of a given parable on more than one occasion and in different contexts, both versions thus go back to the historical Jesus. In Matthew's version of the parable, as indicated above, several redactional features are clearly those of Matthew. These redactional changes make it difficult to understand and support Snodgrass' argument.
Hultgren 2000:336; Stein 1981:90). To this first invitation, Luke adds a second to match his account of the advance of the gospel in his second book (Acts): first to the Judeans (who live, figuratively, in the town), then to the Gentiles (who live, figuratively, outside the town, in the countryside; Funk et al. 1993:352; see also Jeremias 1972:64, Scott 2001:112). Luke finally adds $14: 24$ to reiterate the exclusion of the Pharisees who exclude the lame, poor and blind from the (messianic) banquet (Lk 14:15; Brouwer 1946:224; Funk et al. 1993:352; Hultgren 2000:336). Luke thus not only, like Matthew, allegorises the parable into an image of the history of salvation but also moralises it by emphasising the correct 'how' (do not choose places of honour) and 'who' (inviting the impure and outcasts) when it comes to taking part in or inviting people to a meal.

Below it will be argued that Luke's version of the parable, with the exclusion of Luke 14:24 (and Lk 14:15-16a), has no redactional or allegoristic features when taken out of its narrative context in Luke 14:1-24 and interpreted in terms of the characteristics of a pre-industrial city in 1st-century Palestine - a lens that enables the reader of the parable to identify the realistic features of the parable.

\section{Thomas 64:1-12}

Scholars are divided on the question whether the Thomasine version is dependent on one or both Synoptic versions or based on an independent tradition (see Hultgren 2000:335, n. 8 and 9). Interestingly, a decision on the origin of the Thomasine version plays no role in what scholars see as redactional in Thomas 64. Whether an independent tradition or dependent on one or both Synoptic versions - most scholars see a close parallel with $\mathrm{Luke}^{7}$ - the redactional features identified in Thomas 64 by scholars from both positions are the same. Thomas 64 has four excuses, namely merchants owing money (GThom 64:3), the buying of a house (GThom 64:5), a friend getting married (GThom 64:7) and the buying of an estate (GThom 64:9). Thomas' four excuses - when compared to the Synoptic versions - are either the result of Thomasine redaction (Scott 1989:167; Snodgrass 2008:310) or because Thomas' version is independent (Crossan 1991:261; Funk et al. 1993:352; Hultgren 2000:335). Scholars on both sides also agree that the Thomasine version fits the anti-wealth and anti-business stance of Thomas 63-63, emphasised by Thomas' addition of Thomas 64:12 (Crossan 1973:70-71; 1991:261; Funk et al. 1993:352; Funk et al. 1988:43; Perkins 1981:95; Scott 1989:167; Snodgrass 2008:305).

Whether independent or not, Thomas 64 lacks what is typically Jesus (the marginalised) and focuses on the gospels' anti-wealth and anti-business stance ('this-worldly' affairs; Snodgrass 2008:310).

7.According to Scott (2001:112), the main difference between Luke and Thomas' version is that Luke modified the invitation to others whilst Thomas reworked the excuses of those first invited.

8.'Unlike Luke who has three excuses, Thomas has four. We should immediately be suspicious of four excuses, since oral storytelling prefers threes. Furthermore the excuses given in Thomas all have to do with the management of business. Even the excuse dealing with a marriage, which finds a parallel in Luke, has to do with the management of the wedding feast. These excuses fit with Thomas's final warning, "Buyers and merchants will not enter the places of my Father"' (Scott 2001:112). 


\section{Which version?}

Which version of the parable represents the earliest layer of the Jesus-tradition? Most scholars agree that Matthew's version is secondary (see again § 3.1.1). Regarding the Lukan and Thomasine versions, some scholars argue that both versions represent the earliest Jesus-tradition (e.g. Funk et al. 1988:43), some opt for the Thomas version (e.g. Crossan 1973:72, 1991:261; Fitzmyer 1985:1052; Jeremias 1972:63; Perrin 1967:35) whilst others argue for Luke as the 'most original' version. ${ }^{9}$ Luke is deemed 'most original' because the Lukan version is rendered as also interpreted and applied by Luke to fit its context in Luke 14:1-24 (e.g. Scott 1989:163, Stein 1981:83; Young 1989:169).

The position taken here is that Luke's version of the parable is the closest we can get to the earliest layer of the Jesus tradition, and because Luke respected the authenticity of the parable, he did not edit the version of the parable he most probably borrowed from $\mathrm{Q}$. This position is based on the following argument: Luke did not edit the parable to fit the context of Luke 14:1-24 but constructed Luke 14:1-15 to make it possible to add and use the parable of the Feast in the way he wanted to. This is not the only instance in the gospel where Luke uses this narrative technique. Another example is Luke's use of the parable of the Friend at Midnight (Lk 11:5-8). This parable, when Jesus told it, most probably criticised the practice of some peasants who, when in dire straits, decided to practise balanced reciprocity by imitating the exploitative elite. In this way, they dismissed the shared social value of hospitality and the practice of generalised reciprocity, namely to give without expecting any return by treating neighbours and friends as kin (see Van Eck 2011a:1-12). When Luke uses the parable, it is sandwiched between his version of the Lord's Prayer (Lk 11:1-4) and three short 'askreceive' sayings (Lk 11:9-13) - with persistent prayer as the topic (a typical Lukan theme). Because of this narrative fit, the parable becomes an example of how one should be persistent in prayer. The context thus determines its meaning.

We have the same situation in Luke 14:1-24. By adding the parable of the Feast (Lk 14:16b-23; see below) to a carefully constructed narrative in Luke 14:1-14 and providing it with an introduction (Lk 14:15) and a fitting conclusion (Lk 14:24), the parable's meaning has become predetermined. The parable becomes either a symbol to portray the future messianic banquet or a symbol of the history of salvation. Put differently, Luke's use of the parable makes it possible to interpret the parable allegorically because he constructed a narrative 'fit' for the parable. This is something else than arranging a different version of the parable for a theological purpose, as Snodgrass (2008:306) argues Luke did. The allegorical meaning of the parable in Luke 14:1-24 is not because of Luke's so-called redactional changes of the parable but because of Luke's narrative use of the parable.

9.Scholars who support this position are, for example, Bailey (1983:105), Hendrickx (1986:133), Hultgren (2000:339), Linnemann (1980:90-92), Manson (1951:130), Marshal (1986:133), Hultgren (2000:339), Linnemann (1980:90-92), Manson (1951:130), Marshall
(1978:586-587), Perrin (1967:113), Smith (1937:203), Weder (1978:185-190) and $(1978: 586-587)$,
Weiser (1971:64).
Luke's narrative technique in Luke 14:1-24 - as indicated - is first parable and then constructed context, not first context and then constructed parable.

My argument finds support in a remark from Crossan. Crossan (1973:70), in his discussion of the possible editorial activity in the extant versions of the parable, refers to the odd discrepancy between Luke 14:12 and 14:16b-20. In Luke $14: 12$, Jesus explicitly states that, when one invites people to a dinner, one should not invite the rich. However, this is exactly what happens in Luke 14:16b-20; the host first invites the rich and only after their refusal, the poor, crippled, blind and lame. It can be surmised that Luke, if he did redactionally edit the parable to follow Luke 1:1-14, would have redactionally addressed this discrepancy. Luke did not, most probably because he respected the version of the parable he borrowed from $Q$ and also because the discrepancy did not impact on the theological purpose he wanted to achieve.

The above line of argument begs the question regarding several scholars' opinion that, because of Luke's redactional activity in Luke 14:16-24, the first invitation in Luke 14:21 should be seen as paralleling Luke 14:13. The reason for this argument is that, because inviting the poor, crippled, blind and lame is a favourite Lukan theme, the parable has been edited to include this Lukan motif. If the argument made above holds, the direct opposite should rather be assumed: Because eating with the poor, crippled, blind and lame was so important for Jesus, Luke included it in Luke 14:1-14. A decision on this point is important for the understanding of the parable in the context of 27-30 CE, as will be indicated below. Did the 'typically Lukan' became the 'typically Jesus' in the parable, or did what was typical of Jesus influence the narrative context that Luke created and in which he used a Jesus parable? This is the important question.

\section{Integrity}

Luke 14:15, 23 and 24 are in dispute regarding the integrity of the parable. Although a few interpreters do see Luke 14:15 as part of the original parable (e.g. Stein 1981:86), it is a Lukan creation linking the parable with Luke 14:1-14 and especially with the macarism in Luke 14:14 (Brouwer 1946:224; Hendrickx 1986:113). Luke 14:15 is Luke's introduction to the parable, the lens through which he wants the hearer to understand an original Jesus-parable: At the eschatological banquet, those who excluded the poor, crippled, lame and blind (Lk 14:13; 21) will themselves be excluded. Since Jesus, in his parables at least, did not conceive of the kingdom as an eschatological entity, this verse cannot be traced to the earliest layer of the Jesus-tradition (see Van Eck 2009a:1-12) ${ }^{10}$.

The arguments of scholars who argue for the authenticity of Luke 14:24 differ. Interestingly, some make use of the same arguments to include the verse others use to exclude Luke 14:24. Hendrickx (1986:120), for example, argues that Luke

10.Contra Manson (1951:129), who argues that Luke 14:15, as an introductory statement to the parable, is 'probably too good to be invented'. See also Bailey $(1983: 89)$ for the same evaluation of Luke 14:15. 
14:24 was part of the pre-Lukan source to emphasise the great number of people the host wanted to fill his house, and Groenewald (1973: 200) accepts that Luke 14:24 refers to Jesus' divine mission to the Gentiles at the earliest level of the parable's tradition. Young (1989:176) also defends the originality of the second invitation, but for a different reason, namely that Luke 14:24 stresses the urgency of Jesus' message.

According to Snodgrass (2008:691, n. 259; see also Bailey 1983:109; Marshall 1978:591), Luke 14:24 was not originally part of the parable of Jesus. This view can be supported by the following arguments: Luke 14:24, firstly, forms an inclusio with Luke 14:15 (Kilgallen 2008:82; Scott 1989:164; Swartley 1997:185). Since Luke 14:15 was not part of the original parable, Luke 14:24 should per se be excluded. Secondly, all three extant versions of the parable end with a conclusion fitting the specific version (Mt 22:14; Lk 14:24; GThom 64:12; see Scott 1989:168). Thirdly, the use of $\lambda \dot{\varepsilon} \gamma \omega$ viñv [I tell you, pl.] in Luke 14:24 is odd. Throughout the parable, the host addresses a single servant (Lk 14:17, 21, 23). One should therefore have expected $\lambda \varepsilon \dot{\gamma} \omega$ ooí [I tell you, sing.] (Hultgren 2000:338). Why this shift from the singular to the plural? In Luke (see e.g. Lk 10:24, 11:8; 12:4, 27; 13:24; 15:7, 10; 16:9; 18:8,

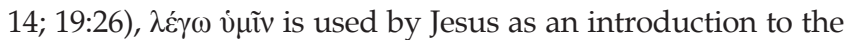
final judgement (Jeremias 1972:177). Because this use of $\lambda \varepsilon \dot{\gamma} \omega$ v $\mu \mathrm{i} v$ fits the eschatological slant of Luke's parable, Luke uses $\lambda \dot{\varepsilon} \gamma \omega$ viñv, conforming to its use as a pronouncement formula in the gospel (Hultgren 2000:338). Luke 14:24 thus should be attributed to Luke's redactional activity (see also Funk et al. 1993:352; Schottroff 2006:52).

The point of view taken here is that Luke 14:24 is most probably a Lukan creation. In this final verse of the Lukan parable, the Lukan Jesus makes clear who the people are who will be excluded from the messianic banquet. They are the Pharisees (Lk 14:1), who pick the places of honour at the table (Lk 14:7); who only eat with friends, relatives, neighbours and the rich and who refused the invitations of the host (Lk 14:18-20). As a group, they are typified by the Pharisee of Luke 14:15, who believes that one can constantly seek honour and exclude those without honour and still be part of the final banquet. Luke 14:24 binds the narrative of Luke 14:1-24 neatly into a unit and states the consequences for those who have rejected the invitation (Snodgrass 2008:691, n. 259; see also Weder 1978:186). ${ }^{11}$ In the parable's narrative context, Luke 14:24 indeed fits. Without it, Luke's use of the parable, metaphorically speaking, has no 'final nail in the coffin'. Without the context, the parable does not need Luke 14:24. In fact, without the context, it does not 'fit'.

Several scholars deem Luke $14: 23$ as a Lukan addition to the original parable, but for different reasons. Some argue that Luke added Luke 14:23 because of Luke 14:13 (e.g. Scott 1989:165). Those who read the parable as a history of salvation argue that Luke added Luke 14:23 to include the

11.Derrett (1976:141) also argues that Luke 14.24 should be seen as the denouement of the parable but for a different reason. According to him, Luke 14:24 does not make clear who will be excluded from the final messianic banquet; it is the refusa of an angered host to send portions of his meal to the absent guests.
Gentiles (Bailey 1983:101-106; Drury 1985:123; Fitzmyer 1985:1053; Funk et al. 1993:352; Swartley 1997:186; Vögtle 1996:78-79) whilst those who read the parable as a reference to the messianic banquet argues that Luke added the verse to emphasise the great number of people the host wanted to fill his house (Hultgren 2000:338; Jeremias 1972:64). Jeremias (1972:64) also opines that, in the extant versions of the parable, only Luke has the second invitation and should thus be seen as secondary.

In the social-scientific and realistic reading of the parable that follows, Luke 14:16a-23 is seen as the parable closest to the earliest Jesus tradition. Luke 14:15 and 24 are excluded on the basis of the arguments above. Luke 14:23, however, is included. This inclusion is not based on the arguments normally put forward for inclusion by parable scholars. The basis for inclusion is verisimilitude. Luke's version of the parable is realistic when compared to the common features of the pre-industrial city in advanced agrarian societies. This point of departure is based on the work of Rohrbaugh (1991:151-180) and will be discussed below in detail. Luke's version of the parable, taken out of its context in Luke 14:1-24 and interpreted inter alia from this perspectival lens, is not an allegory or a metaphor. It is a parable, an a-typical story of what was typical in the world of Jesus and the hearers of the parable (see Van Eck 2009a:1-12).

\section{A social-scientific interpretation of Luke 14:16b-23 Interpretations of the parable employing
aspects of a social-scientific reading}

Only a few scholars have thus far subjected the parable to a social-scientific reading, albeit with limited scope. Scott (1989:161-174) focused on the social function of meals, the honour-shame culture of 1st-century Palestine, reciprocity and purity (the marginalised). Snodgrass (2008:308) also refers to meals as a means of organising Mediterranean society and the pivotal role played by honour and shame in the world of Jesus. These social values, however, do not play any significant role in his analysis of the parable. Donahue (1988:144-145) attends to purity and pollution as key to understanding social and cultic boundaries in first century Palestine and the way in which the parable shatters these boundaries, boundaries that will only be shattered when the community celebrates the eschatological meal.

An exception is Rohrbaugh's social-scientific reading of the parable (see Rohrbaugh 1991:151-180, 2001:239-259). Rohrbaugh focuses on the social function of meals as ceremonies, honour and shame, reciprocity, purity and pollution, friendship and patronage. His contribution regarding the social function of gossip and the characteristics of the pre-industrial city is especially noteworthy. Work done by Rohrbaugh not only opens up the social world of the parable but, importantly, enables a realistic reading of the parable. Several aspects of the reading of the parable which follows are indebted to his work. 


\section{Luke 14:16b-23: An emic reading}

The parable is a story about a man (host) who prepared a feast and invited many guests (Lk 14:16b). When the feast was ready, he sent his servant to tell those who had been invited to come (Lk 14:17). The invited guests all alike began to make excuses, giving reasons why they could not come. The first guest had bought a field and had to go to inspect it, the second guest had bought five yoke of oxen and was on his way to try them out and the third guest had recently been married and could therefore not attend (Lk 14:18-20). When the servant informed the host about the turn of events, the host became angry and sent his servant to the streets and alleys of the city to invite the poor, crippled, blind and lame (Lk 14:21). The servant did what was ordered and then reported back to his master that his house (banquet) still had some places left (Lk 14:22). The master then sent his servant to invite the people who lived on the roads and country lanes to fill up the feast he had prepared (Lk 14:23; see Van Eck 2012:4).

\section{Luke 14:16b-23: An etic reading}

An emic reading (native's point of view) of the parable evokes several cultural norms (social values) of the 1st-century Mediterranean world that are implicitly embedded in the parable. These social values (cultural scripts) were part of the repertoire of the teller and audience of the parable - a shared cultural world of references that resonates in the parable (see Scott 2001:109-117).

Embedded in the story are social values that play a role in the dynamics of the parable. They include at least the following: The feast is a meal and thus a ceremony (boundary making) in which purity and status plays a role, the extension of invitations implies the pivotal role of honour as well as patronage and accepting an invitation in the 1st-century Mediterranean world implied reciprocity. Also embedded in the parable is, as Rohrbaugh (1991:151-180, 2001:239-259) has indicated, the social role that gossip played in the world of its audience. Finally, if the modern interpreter of the parable wants to avoid the fallacies of ethnocentrism and anachronism, the characteristics of the pre-industrial city as a backdrop (social setting) to the parable, the social dynamics implied by inviting guests in the 1st-century Mediterranean world and the reasons why guests excused themselves should also be taken into consideration.

\section{The backdrop to the parable: The pre-industrial city}

In pre-industrial cities, social status, honour and location of dwelling went hand in hand, with walls clearly demarcating who belonged where and gates controlling the interaction between the different social groups that inhabited the city. The elite occupied the walled-off centre of the city, with the non-elites occupying the outlying area of the city located between the inner and outer walls of the city (see Rohrbaugh 1991:133-146). Inside the city walls the elite and non-elite thus were physically and socially isolated from one another (Rohrbaugh 1991:134). The centre of the city normally contained the palace, the temple and the residences of the political and religious elite, that is, those with honour, status, power and privilege (Rohrbaugh 1991:134). The city centre, apart from having its own internal walls, was clearly demarcated from the rest (outlying area) of the city with an inner wall. Occupation of this outlying area (between the inner and outer wall) was normally organised in terms of particular families, income groups, guilds, ethnicity and occupation (Rohrbaugh 1991:134-135). Living conditions in this area were not pleasant:

Most streets were unpaved, narrow, badly crowded and would not have allowed passage of wheeled vehicles. Many would have been chocked with refuse and frequented by scavenging dogs, pigs, birds, and other animals. (Rohrbaugh 1991:135)

The pre-industrial city, finally, also 'housed' a third group of people, the socially ostracised, consisting of prostitutes, beggars, tanners and other social outcasts like lepers (see Rohrbaugh 1991:135). People who were part of this group lived outside the outer walls of the city and were only allowed to enter the city during the day to look for work as day labourers, for example.

The pre-industrial city was thus an example of what can be called 'human territoriality' (Rohrbaugh 1991:136), 'the attempt by an individual or group to affect, influence or control people, phenomena, and relationships, by delimiting and asserting control over a geographical area' (Sack, cited by Rohrbaugh 1991:136). What is important in understanding the parable is that social contact between the different groups, especially the elite and non-elite, was nearly non-existent. As put by Rohrbaugh (1991):

A member of the urban elite took significant steps to avoid contact with other groups except to obtain goods and services. Such a person would experience a serious loss of status if found to be socializing with groups other than his own. Thus social and geographical distancing, enforced and communicated by interior walls, characterized both internal city relations and those between city and country. (p. 136)

Below it will be indicated that the characteristics of the preindustrial city are an important lens to understanding the implications of the third and final invitation in the parable of the Feast when the slave is ordered to go and invite those in the streets and alleys of the city ( $\tau \grave{\alpha} \varsigma \pi \lambda \alpha \tau \varepsilon i \alpha_{\varsigma} \kappa \alpha i ̀ ~ p o ́ \mu \alpha \varsigma \tau \tilde{~}{ }_{\varsigma}$ $\pi$ ó $\lambda \varepsilon \omega \varsigma ;$ Lk 14:21) and then those in the roads and country

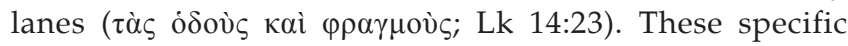
references do not only place the story of the parable firmly in the social location of a pre-industrial city, but it also spells out the implications these invitations had for the host.

\section{The social dynamics of invitations in the 1st-century Mediterranean world ${ }^{12}$}

Greek papyri, found in Egypt, that have as content invitations to dinners indicate that the structure and form of these invitations were likely used to invite people to the type of dinners mentioned in the New Testament (see Kim 1975:391402). Most of the invitations have the same form, including an invitation-verb; the names of the invited guest and host; 12. This discussion on the social dynamics of the invitations and excuses in the parable
(see below) makes extensive use of an earlier article in which gossip as 'social game' was discussed (see Van Eck 2012:1-10). 
the purpose and occasion of the dinner and the date, time and venue where the dinner was to take place. Importantly, most of them either have or suggest that a double invitation to a dinner was commonplace. ${ }^{13}$ This means that the two invitations in the parable can be considered as realistic (verisimilitude) and drawn from the life and customs of 1stcentury Palestinian Judaism (Stein 1981:84). ${ }^{14}$

How do scholars interpret the invitations in the parable? According to Scott (1989:171), the invitations referred to in the parable (Lk 14:16b and 17) were normally written by hosts and then conveyed orally (or read) by messengers to possible guests some time before a dinner. It was then followed with a courtesy reminder or second invitation with the messenger (most probably a slave) escorting the guest(s) to the dinner. According to several scholars, evidence of this practise is found in the Near-Eastern custom of slaves arriving to announce that a banquet was ready (Hultgren 2000:333; Hunter 1971:93, 1976:57). Also, according to Jeremias (1972:176), the second invitation was a special sign of courtesy practiced by the wealthy elite in Jerusalem (see also Linnemann 1980:87; Perkins 1981:97; Scott 1989:169).

What was the purpose of this double invitation? Firstly, the first invitation gave the invited guests ample notice of an occasion to which they were invited, an invitation to which they had to respond (e.g. Crossan 1973:73, 1991:261). Secondly, as argued by Bailey (1983:94), a host had to prepare for the meal (e.g. proper meat), and for this, the host needed to know how many people would attend (see also Lockyer 1963:275). The first invitation helped to know how many people would attend and how much food had to be prepared (Wenham 1989:136). The first invitation was serious, and 'acceptance of it ... a firm commitment, since the host prepares the amount of food on the basis of how many accepted the invitation' (Bailey 1983:94). Guests who accepted the first invitation were duty-bound to appear (Bailey 1983:94; see also Timmer 1990:56). The second invitation was only extended if the first invitation was accepted, and this happened at the hour of the banquet (Kistemaker 1980:163). The second invitation was thus 'a courtesy reminder, extended only to those guests who previously accepted the invitation' (Scott 1989:171).

This 'consensus-understanding' amongst most scholars concerning the purpose of double invitation is anachronistic, a nice fit of how things are done in the world to which modern interpreters of Biblical texts belong. Much more is at stake here. Below it will be argued that, from a socialscientific point of view, the first invitation should rather be seen as a challenge of honour. Furthermore, the purpose of the second invitation could only be determined when gossip

13.See, for example, Esther 5:8 and Esther 6:14, Apuleius (Metamorphoses 3.12) Gospel of Thomas 64:1, Midrash Rabbah Lamentations 4.2, Sirach 13:9, Plutarch (Moralis 511D-E) and Philo (De Opficio Mundi, XXV.1.78). For examples from Greek papyri, see Kim (1975:393).

14.Contra Crossan $(1973: 73,1991: 261)$, who argues that, if the plot behind all three extant version of the parable is taken into consideration, there were no first invitations. The feast was unannounced, and because of the untimeliness of the invitation, the excuses offered were perfectly reasonable. See Rohrbaugh (1991:139, 141) for a critique of Crossan's point of view, 'a view that we suggests is a simple but obvious anachronism on the part of a modern interpreter with a busy schedule' but obvious anachronism
(Rohrbaugh 1991:141). as a social game - that was part of the world of the parable is taken into consideration.

\section{Gossip $^{15}$}

In the majority of oral (non-literate) cultures like that of the parable, gossip was quite often the only way to obtain information (Paine 1967:282; Malina \& Rohrbaugh 1998:103). Gossip, in its cultural form, was understood as a 'sort of game' (Gluckman 1963:307), a 'catalyst of social process' (Paine 1967:28-30), a necessary and positive social activity of informal social bonding and formation, control and order (Abrahams 1970:296; Gluckman 1963:307; Paine 1967:278). In oral societies, gossip was an institutionalised means of informal communication, interwoven in the daily affairs and interactions between people, and everybody partook in it (Andreassen 1998:41).

Gossip as 'a naturally recurring form of social organisation' (Handelman 1973:212) or 'cultural form' (Spacks 1985:15) can in short be defined as conversations or critical talk about absent third parties (see Daniels 2008:38-39; ${ }^{16}$ Gilmore 1987:92; Haviland 1977:28; Hunter 1990:300). This definition implies the following as characteristics of gossip, namely, (1) gossip is 'signed' or face-to-face-talk about people who are not present (Rohrbaugh 2001:241); (2) for gossip to occur, it requires participants to know each other, understand the import of the situation and share evaluative categories (Yerkovich 1977:192); (3) gossip overlaps with simple wordof-mouth 'news' about what is going on (Rohrbaugh 2001:241) and is often the principle means of information-exchange in oral villages (Arno 1980:343; Paine 1967:282); (4) gossip is evaluative talk and usually implies assessment of one kind or another (Rohrbaugh 2001:241); (5) it normally serves the interests of individuals (self-interest) and the groups to which individuals belong (Rohrbaugh 2001:241); and (6) its main cause is often the intense competition for public reputation (honour; Rohrbaugh 2001:245) and community status (personal power; Abrahams 1970:292).

These characteristics imply several social functions of gossip as a controlled cultural form. Rohrbaugh (2001:251-256) identifies the following four social functions of gossip (see also Malina \& Rohrbaugh 1998:103): (1) clarification (consensus building), maintenance (reaffirmation) and enforcement (sanction) of group values; (2) group formation and boundary maintenance; (3) the moral assessment of individuals; and (4) leadership identification and competition.

The above characteristics and social functions of gossip imply that gossip will take place where there is agreement

15.This section is a reworked version of the description of the function of gossip in oral cultures as described in Van Eck (2012:1-4). For a more extensive description of the definition, characteristics and social function of gossip as a necessary social game in the 1st-century Mediterranean world, see Van Eck (2012:1-4).

16.Daniels' defines gossip as follows: 'Gossip is face-to-face communication involving at least two persons, two groups, or a single group, engaged in transacting information, either positive or ne tive in character, about a third-party subject who is either either positive or negative in character, about a third-party subject who is either actually absent or rendered absent to the conversation. A gossip encounter occurs as a response to a generative event, or reports such an event, that undercuts or (relenges the established social-cultural (re)assert or (re)construct reality" (Daniels 2008:38-39). This definition of Daniels is noteworthy since it incorporates the characteristics, social function, reason and aim of gossip as a social game. 
on the norms and values of a specific community (Daniels, in following Foster 2004:86). Daniels (2008) continues:

Thus, for someone to become the subject of gossip, that one must do something to draw attention to him/herself, usually something that goes against social norms, or undercuts the managed impression of the way things or individuals should be ... In other words ... for a gossip event to occur there must be an unexpected or unusual event that causes it, at least two persons engaged in the communicative event (gossiper and listener), a third party subject of the gossip, and some sort of social setting where ... persons normally get together to socialize. (pp. 17-18, 30)

From the above, it is clear that gossip, and status and honour, went hand in hand. Gossip reinforced behavioural norms, and conformity to these norms developed social reputation and competition for acquired honour. Gossip was, in quoting Gluckman (1963:309), 'one of the chief weapons which those who consider themselves higher in status use to put those whom they consider lower in their proper place.' Competition for honour, social ranking and higher status thus went hand in hand with gossip. As put by Rohrbaugh (2001):

The point, then, is that in the degree to which evaluation or moral judgment is involved, gossip becomes a way of manipulating moral status (acquired honour) or other prospects in the 'interests' of some person or group. (p. 242)

Since 'competition for reputation ... is a matter of honour, and honour is the core value in the Mediterranean world' (Rohrbaugh 2001:243), it is clear that gossip played a pivotal role in the maintenance of one's honour in the Mediterranean world. Failure of any kind, but especially failure to defend honour, was therefore always the subject of gossip (Campbell, in Rohrbaugh 2001:243).

Below it will be indicated that the three excuses in the parable, when interpreted through the lens of gossip as a social game in oral cultures, can help the modern interpreter of the parable to avoid an ethnocentristic interpretation of these excuses.

\section{Meals as ceremonies: Honour and shame, patronage, reciprocity and purity}

In the Mediterranean world, meals taken together were seen as a confirmation of shared values and structures, status and honour rating. Taussig (2009) phrases it as follows:

When people gathered for meals in first-century Mediterranean cultures, the event was laden with meaning. Meals were highly stylized occasions that carried significant social coding, identity formation, and meaning making. Participating in a meal entailed entering into a social dynamic that confirmed, challenged, and negotiated both who the group as a whole was and who the individuals within in it were. (p. 22)

It is further argued by Douglas (1975):

If food is treated as a code, the message it encodes will be found in the pattern of social relations being expressed. The message is about different degrees of hierarchy, inclusion and exclusion, boundaries and transactions across the boundaries. (p. 249)

From a social-scientific point of view, meals are ceremonies - events that occur regularly, are called for and function to confirm roles and statuses within a given group (Neyrey
1991:363). Meals-as-ceremonies bolster the boundaries that defined specific groups, confirm established roles and statuses and attend to stability and continuity; it replicated a groups' basic social system, values, lines and classifications (Neyrey 1991:363).

Because meals had to do with different degrees of hierarchy, inclusion and exclusion and boundaries, likes only ate with likes, that is, people ate with others of the same social standing, status and honour rating. This means that the elite, who occupied the walled-off centre of the city, only ate with (certain) elite within the inner wall but not with the nonelites occupying the outlying area of the city located between the inner and outer walls of the city or those (the impure and marginalised) who lived outside the city walls. Contact between the elite and the latter two groups were nearly nonexistent, and where contact did take place, it was mainly for economic reasons (goods and services); socialising and eating together simply did not take place.

The 'social dynamic' of meals, referred to by Taussig above, also relates to what is known as reciprocity (the way in which goods were exchanged in 1st-century Palestine; see Malina 1986:98-106) and patronage. Reciprocity between equals, known as balanced reciprocity (the idea of quid pro $q u o$ ), meant that an invitation to a meal was to be followed by the same kind of invitation to the one who invited a person first. An invitation to a meal, in short, increased the social indebtedness of others to the host (Scott 1989:169). Patronage, in this context, is a form of reciprocity. If a host distributed food, what would he want in return (see Neyrey 1991:374)? Attending a meal in the 1st-century Mediterranean world was thus serious business.

What will an etic reading of the parable look like when interpreted against the backdrop of the pre-industrial city and through the social-scientific lenses of meals as ceremonies, purity, gossip, status, honour, patronage and reciprocity? To this we now turn.

\section{Reading the parable}

Luke 14:16b sets the scene for the parable: A certain man

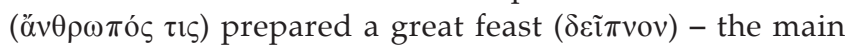
meal Jews usually ate in the evening ${ }^{17}$ - and invited many ( $\pi$ o $\lambda \lambda$ ov̀ $\varsigma$ ) guests ${ }^{18}$. Although the host of the feast is simply

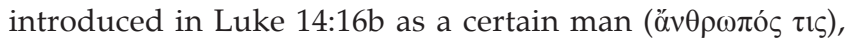
in can be deducted from the parable that he was a wealthy person. The host has the means to entertain 'many' ( $\pi$ o $\lambda \lambda$ ov̀ $\varsigma$ )

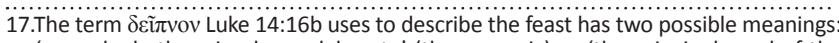
'a meal whether simple or elaborate' (thus generic) or 'the principal meal of the day, usually in the evening - 'supper, main meal' (Louw \& Nida 1988:252); see also Hultgren 2000:336). Louw and Nida (1988:252), Strack and Billerbeck (1974:207) as well as scholars like Stein (1981:84) and Linnemann (1980:88) connect the second meaning to Luke 14:16b. The Jews in Palestine, unlike the Greeks who ate three meals a day and the Romans who ate four, normally ate only two meals - the first was a late breakfast, and the second was in the evening when there was no longer sufficient light to work (Stein 1981:84, 159, n. 3-5). Luke's use of $\delta \varepsilon i \pi v 0 v$ most probably refers to the second meal the Jews ate (Stein 1981:84; Linnemann 1980:88).

18.In the interpretation that follows, the parable is divided into eight scenes: (1) the preparation of the feast and a first invitation (Lk 14:16b); (2) a scene not narrated (see below); (3) a second invitation (Lk 14:17); (4) the excuses (Lk 14:18-20); (5) first report back of the slave and the reaction of the host (Lk 14:21a and 21b); (6) first report back of the slave and the reaction of the host (Lk 14:21a and 21b); (6)
a third invitation (Lk 14:21c); (7) second report back of the slave (Lk 14:22); and (8) the fourth invitation (Lk 14:23) 
with a big feast $(\delta \varepsilon \tilde{i} \pi v o v \mu \varepsilon \dot{\gamma} \alpha)$ and has the services of a slave (Lk 14:16b, 17, 20-23). He was, as Bailey (1983:94) puts it, a

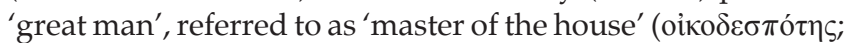
Lk 14:21) and addressed by his slave as 'master', lord' or 'owner' (кúpros; Lk 14:21, 22, 23). The double invitation in the parable further illustrates the man's wealth since the double invitation was a special sign of courtesy practiced by the wealthy (Scott 1989:169). This description of the host of the banquet places him amongst the urban elite, 'a leading member of that urban group which both sets the terms for and controls access to social interaction between itself and others in the society' (Rohrbaugh 1991:140). Finally, if those invited in Luke 14:21 and 23 - the people living inside the city between the inner and outer walls in the wider streets and squares and the narrow streets and alleys ( $\tau \dot{\alpha} \varsigma, \pi \lambda \alpha \tau \varepsilon i$ s $\varsigma$

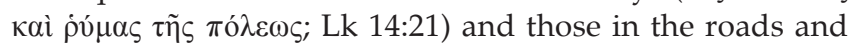

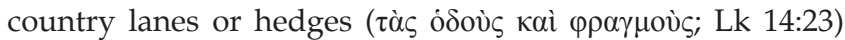
outside the city walls (Rohrbaugh 1991:144) - are understood as the socially impure (expendables, see Duling 2012: 67-71), the host was most probably a Jew (see Van Eck 2012:5). ${ }^{19}$ Clearly the host was thus one of the elite who occupied the walled-off centre of the city.

Since likes only ate with likes in the 1st-century Mediterranean world (people with the same social standing, status and honour rating), it can be supposed that the invitees of Luke 14:18-20 were also part of the elite who occupied the walled-off centre of the city. As argued by Van Eck (2012:5), the parable gives us enough information in the excuses of three of the many guests invited to the feast to draw this conclusion. The first invitee acquired a piece of land. No peasant would sell land if it was not the final option. Because of taxes (extracted by the elite) and high interest rates on loans (made available by the elite), many peasants in 1st-century Palestine lost their land or had to sell it (see Van Eck 2009a:4-5). Available land was normally bought by the elite who had the means to acquire land, and much of the land outside of cities in 1st-century Palestine was indeed owned by the elite (see Rohrbaugh 1991:142-143). The person behind the second excuse was also one of these landowning elite. According to Jeremias (1972:177), the general size of the land of a peasant farmer was more or less 10-20 hectares which needed 1-2 yoke of oxen to plough. In Luke 14:19, the person bought five yoke of oxen, which means that the land he owned was at least 50 hectares in size. If one also takes into consideration that, normally, half of a land was left fallow each year, a landowner needing five oxen was the owner of a very large piece of land (see Rohrbaugh 1991:143). ${ }^{20}$ The third guest that recently got married (Lk 14:20) most probably was also part of the elite, although in his case, only indirect inferences can be made. Marriage in the Mediterranean world was always arranged by parent and went hand in hand with honour and status, as well as political and economic concerns (see Van

19.Jeremias (1972:178-179) is very specific in his description of the host - the man is a tax gatherer who became wealthy and invited people from the highest circles to endorse his new position. There is no evidence in the parable for such a clearcut description. Schottroff (2006:50-53), reading the parable in the context of the Jewish tradition of loving deeds and the rights of the poor in the sense of Israel's Torah, also depicts the host as a well-to-do Jewish man.

20.The estimates by Schottroff and Stegemann and Oakman (see Rohrbaugh 1991:143) of the size of land owned by peasants in 1st-century Palestine as well as the size of the land owned by the person who bought five yoke of oxen concur with this conclusion.
Eck 2007:104-108). Since this guest was on the list of those invited, he most probably was in the same honour, economic and political league as the other invitees. ${ }^{21} \mathrm{He}$ was therefore also one of the elite, as were the rest of the 'many' (Lk 14:16b) invited who also did not show up at the feast. Since likes only ate with likes, the other guests most probably were of the same status.

From an etic perspective, the scene set by Luke $14: 16 \mathrm{~b}$ is thus that of a Jewish elite inviting other elites - all who occupied the walled-off centre of the city - to the main meal of the day (supper). The parable then continues with three scenes of which only the third (the second invitation) and fourth scene (some of the guests excusing themselves) are narrated. The second scene is not narrated, namely what happened 'backstage' between the first and second invitation. This nonnarrated event (second scene) is important to understand the parable; it binds the first four scenes of the parable as a unit and serves as stimulus for the final four scenes of the parable (see again n. 17).

In the first four scenes of the parable, when looked at as a unit, the host follows the typical Near-Eastern custom practiced by the wealthy elite by extending two invitations to his potential guests, who then all excused themselves. To understand the social dynamics of these four scenes, it is necessary to look more closely at the excuses offered and to revisit the purpose of the double invitation (the first two invitations) in the parable.

The three excuses in Luke 14:18-20 are interpreted by scholars in more or less four ways (with some scholars having more than one opinion; see Van Eck 2012:6-7). The first point of view is that the excuses have to be interpreted in terms of orality and storytelling, in other words, in terms of their intended effect on the parable. According to this position, the excuses are hyperbolic (Weder 1978:187), exaggerated (Funk et al. 1993:352) and absurd (Jeremias 1972:178). This, however, can be explained: Although most unusual, 'in the parables unusual actions such as this are frequently portrayed and would be accepted as part of the storyteller's freedom in telling the story' (Stein 1981:85). The excuses should thus be understood in terms of the rule of good storytelling (Hultgren 2000:336), as evidence of the rule of three and the economy of the parables of Jesus (Snodgrass 2008:306). Also, the use of threes in the parable (the three invitations and three excuses) helps to aid the memory and is evidence that the parable was formulated and passed down orally (Funk et al. 1993:352).22 A second position sees the excuses as valid, especially when the untimeliness of the invitations is taken into consideration. Crossan (1991:261), for example, opines that the excuses are valid and extremely polite, as does Perkins (1981:97) - the excuses are 'acceptable or at least probable excuses in polite

21.'Marriages in antiquity were made by extended families, not individuals, and were parentally arranged; they were not agreements between a man and a woman who have been romantically involved ... [I]ndividuals really did not get married. Families did. One family offered a male, the other a female. Their wedding stood for the wedding of the larger extended families and symbolised the fusion of honour of both families involved. It would be undertaken with a view to political and/or first-century Israel' (Malina \& Rohrbaugh 1988:28, 240).

22.The excuses thus lack verisimilitude and cannot be related to the possibility that all the invited guests, for a specific reason, indeed excused themselves. 
form'. Funk et al. (1993:354) interprets the excuses in the same vein; the three invitees refuse for quite legitimate reasons ${ }^{23}$, 'in accordance with the regulations that allow those conscripted to complete essential tasks' ${ }^{24}$

The third and minority position is that of Linnemann (1980:89). The excuses, Linnemann argues, are not weak excuses but a notice to the host that they will indeed come but that they will be late. After all, one is in the act of buying a field and another has to go and try out five yoke of oxen. ${ }^{25}$ The fourth and dominant interpretation is that the excuses are flimsy and spurious and do not stand the test (Bailey 1983:94; Boice 1983:89; Hultgren 2000:336; Jeremias 1972:179; Kilgallen 2008:84-85; Kistemaker 1980:163; Scott 1989:169; Snodgrass 2008:687; Wenham 1989:136). No one buys a field before inspecting it, buy five oxen before testing them out or accept an invitation to a banquet and forget that he was getting married or decide to spend time with the unimportant sex (a woman) if one can spend it with a man (Bailey 1983:99; Scott 1989:169; Snodgrass 2008:687) - all tasks that could have been done on any other day (Kilgallen 2008:86). The excuses are insulting (Bailey 1983:94; Wenham 1989:136) or even deliberately insulting and extremely offensive. By accepting the first invitation, it became a command that had to be honoured (Hultgren 2000:336; Kistemaker 1980:163).

These four interpretations of the excuses in the parable, firstly, focus on the content of the excuses with a typically modern approach to true or false (see Van Eck 2012:7). To be fair, some interpreters do refer to the same spirit and essence of the excuses, namely that it seems that the invitees did not want to go (see e.g. Kistemaker 1980:163; Lockyer 1963:276-277; Morgan 1953:181-182; Schippers 1962:41; Scott 2001:109-117). Even if this was the case, the three given excuses are not related to the deafening silence of the other invited guests (the many invited). The question should not be why the three did not attend the feast but why everybody turned down the invitation. Secondly, even when one focuses on the content of the three excuses in Luke 14:18-20, the stock interpretation given by most scholars should not simply be accepted at face value. Luke 14:1-20 does not suggest that a field was bought before any inspection, that the five yoke of oxen were not tested out earlier or that a newlywed all of a sudden forgot that he was getting married. ${ }^{26}$ This is not the point. The point is what lies behind these excuses, and

23.Funk et al. (1993:354) is not clear on this point. Earlier, they state that the excuses are 'most trifling' (see Funk et al. 1993:352).

24.This position seems to be built on the premise that only one invitation was extended to the invitees.

25.This interpretation is built on the content of the rest of the parable - especially the reaction of the host and his reaction to invite other guests instead - but ignores the third excuse and lacks a close reading of the text.

26. Why is it not also possible that the field had already been inspected before and was now going to be inspected for a specific reason? Maybe the new owner had some work done on the plot he recently bought, like ploughing or the possibility of starting to plough because of the season, moving his sheep from one part of the plot to another to manage grazing, fencing or progress with the erection of a dwelling or other project? Why is not considered the possibility that the five yoke of oxen were eing to be tried out on a different kind of terrain with a new yoke of oxen were going to be tried out on a different kind of terrain, with a new driver or plough or even with changing the pairs of oxen around? And why is it not possible that the third person indeed recently got married, but the marriage feast was extended past the normal period feast of seven days (see Ferguson 1987.55, Malina \& Rohrbaugh 1998.70-71)? Many more reasons can be added to these listed here, just as possible or impossible. The validity or invalidity of these possibilities is just the point. It is not about the content of the excuses but about identifying the possible social dynamics behind the excuses. why all the invited turned down the invitation. Thirdly, these interpretations work with the premise that the first invitation implied a definite yes or no on the part of the invitees since a number was needed for the preparation of the banquet. Thus, what is at play here is common courtesy towards a host, a gesture that will make it possible for a host not to be shamed at a banquet where there is not enough to eat or drink. Who, in our modern society, would like to be part of such an embarrassing situation (see Van Eck 2012:7)?

The dominant interpretation of the invitations (see § 4.3.2) and excuses in the parable, which can be called the 'received view', 'exposes our uncritical lenses when interpreting ancient texts that are the product of cultures vastly different from ours', making the interpretations anachronistic and ethnocentristic (Van Eck 2012:7). In an effort to overcome this 'hermeneutical deficit', the relationship between the first two invitations and the excuses in the parable should rather be understood as the result of gossip as a cultural form or social game that was engrained in the cultural world that produced the parable (Van Eck 2012:7).

The purpose of the first invitation (as discussed in § 4.3.2) was not to give ample notice of an occasion that was going to take place, to get the number of guests that would attend or an invitation that expected an answer (see Van Eck 2012:8). In essence, the first invitation was an honour challenge to the invited. ${ }^{27}$ As put by Rohrbaugh (1991):

... a double invitation would have several purposes. Initially the potential guest would have to decide if this was a social obligation he could afford to return in kind. Reciprocity in regard to meals was expected.... But more importantly, the time between the invitations would allow opportunity for potential guests to find out what the festive occasion might be, who is coming, and whether all had been done appropriately in arranging the dinner [the second non-narrated scene of the parable]. Only then would the discerning guest be comfortable showing up. The nearly complete social stratification of pre-industrial cities required keeping social contacts across class lines to a minimum and elaborate networks of informal communication monitored such contacts to enforce rigidly the social code. (p. 141)

What Rohrbaugh clearly implies is that, after the first invitation, the gossip network of the community kicked in (the second non-narrated scene): The invitation extended to many was now discussed (gossiped) in the community with the view of clarification and boundary maintenance and enforcement. The host was assessed morally, and boundary maintenance was taking place.

On the day of the banquet, the second invitation went out (third scene), not only to those who accepted the first invitation but again to all invited. Put differently, on the day of the banquet, the host was inquiring about his honour rating in the community. The answer he receives is not a positive one: He has not made it - peer approval was not forthcoming. This host obviously had an honour rating in the community, as all had. What this rating was is not stated. What we do

27. Contra Snodgrass (2008:313), who argues that nothing in the parable suggests that the host gave his banquet as a quest for honour', although he is also of the opinion that meals in the world of the parable were a means of organising society (see Snodgrass 2008:308). 
know is that the man must have been part of the elite: He was wealthy enough to entertain many and owned a slave. Since meals were occasions that carried significant social coding and identity formation, the host saw himself as their peer and equal, or hoped that by accepting, his guests - who were part of the elite - would either affirm his current honour rating or the rating to which he aspired. However, something was wrong with the feast. What it was, the parable does not say. What is clear is that his invitation was unexpected or unusual and went against the accepted and agreed social norms of the community. The host therefore became the subject of gossip because his honour rating and that of the community were at stake. This can be deducted from the excuses given to his slave, excuses that were, as a result of the gossip that took place, a riposte of the invitees and community to his challenge implied in the first invitation. Again, Rohrbaugh (1991) is spot-on:

Their excuses, seemingly irrelevant to the Western, industrialized mind, are standard fare in the dynamics of honor-shame societies. The point is not the excuses at hand, but social disapproval of the arrangement being made, a point to which their seeming irrelevance contributes. Something is wrong with the supper being offered or the guests would not only appear, social opinion would demand that they do so. (pp. 141-142; [Author's own emphasis])

Thus, what is important in understanding the parable on this point is not the content of the excuses but rather what lies behind them. As indicated above, a few scholars have indeed identified this important aspect of the three excuses in the parable. ${ }^{28}$ None of these scholars, however, saw the social dynamics of gossip as a social game as an explanation and an important key to understanding the excuses.

With gossip as the interpretative key, the three excuses in the parable are not the result of the oral transmission of the parable in its pre-literary form following the rule of threes in good storytelling. Also, it does not matter if the excuses were valid or invalid or a notice of latecomers. In the world of the parable, this does not matter at all. What matters is what the excuses convey: The host is shunned. He played the social game according to the rules but did not make it a result of gossip.

Why can this be stated in such categorical terms? Because no one attended the feast. Not only did the three who excused themselves not attend, but not one of the many others who were invited attended either. The excuses of the three guests represent the outcome of the gossip network operating in the community. Attendance was socially inappropriate. The elite guests played according to the rules, value system and norms of the community:

... their excuses conceal the real reason for the disapproval as the system demands. Nor do they break ranks. If one does not show, none do. None will risk cutting himself off from their peers. (Rohrbaugh 1991:143)

28. Lockyer (1963:276), for example, refers to the same spirit and essence of the excuses Scott (1989:171) notes that the excuses have the appearance of a concerted effort on the part of those invited', and Plummer (1922:54-56) calls the excuses 'a conspiracy. Some also agree that, with the excuses, the host is effectively snubbed (Scott 1989:169), that the excuses indicate some hostility towards the host on the part of those who were invited because they did not like the host and that the invitees 'boycotted the invitation, likely because of some social impropriety' (Braun, in Swartley 1997:186-187)
When the slave reports back to the host that not one of the invited elite was going to attend his feast, he became angry (fifth scene). The reason for this is obvious. Boundaries were drawn, and as a result of gossip, he was rejected and shamed. Those he thought or hoped would see him as a peer rejected him - his honour challenge (invitation) did not make it. Not one of the elite invited was willing to acknowledge him as patron or put them in a position in which they had to reciprocate. What could he do to save face?

What the host then did is the surprising element of the parable. He decided to be a different kind of patron, a patron that is not interested in honour ratings or balanced reciprocity, that is, what he can get out of inviting people to a feast. He sent his slave to invite people living in the wider streets and

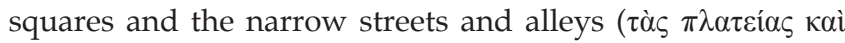

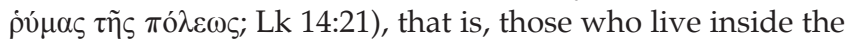
city between the inner and outer walls (scene six). And when the slave reported back that there was still room for more (scene seven), he sent his slave to invite (compel or convince)

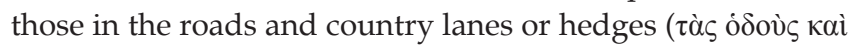

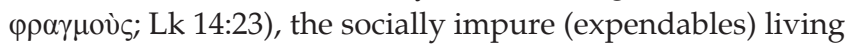
outside the city walls (scene eight).

Thus, whilst the urban elite who were first invited took significant steps to avoid contact with those living outside the inner and outer walls of the city, except to obtain goods and services, the host socialised and ate with them. By this, the host abandoned the ever-present competition for acquired honour in the 1st-century Mediterranean world, replaced balanced reciprocity (quid pro quo) with generalised reciprocity (giving without expecting anything back) and declared the purity system which deemed some as socially and ritually (in a cultic sense) impure null and void. All walls have been broken down, and the world was upside down.

Not, however, from the perspective of the kingdom of God, the point Jesus wanted to make with the parable. In the kingdom, patrons are real patrons when they act like the host: giving to those who cannot give back, breaking down physical (walls) and manmade boundaries (purity and pollution) and treating everybody as family (generalised reciprocity), without being afraid of being shamed. This was the kingdom of God, a kingdom in which the pivotal value of honour that organised and stratified society had no role, a kingdom in which purity did not ostracise and marginalise the so-called unclean or expendables. When patrons are real patrons, the kingdom of God is visible and not the kingdom of Rome (honour) or the kingdom of the temple (purity).

\section{A parable of Jesus?}

The parable, as interpreted above, has all the earmarks of a Jesus parable. Typical of Jesus' parables, it cuts against the social grain and most probably represents the earliest layer of the historical Jesus tradition. It resonates with Jesus' own eating practice (Mt 9:10-13//Mk 2:15-17//Lk 5:29-32; Mt 11:19//Lk 7:34; see also Lk 15:2; 19:5-10), his stance on reciprocity and his attitude towards the temple purity system 
(inclusivity). In terms of the criteria of early, multiple and independent attestation and coherence, the parable displays typical values that Jesus supported - his advocating of general reciprocity, his challenge to the laws governing pollution and purity and the reversal of status, namely that those who are part of the kingdom are like real brothers and sisters (in the sense of fictive-kin).

Jesus' stance in the parable on general reciprocity echoes his sayings in Q 6:34-35 (Mt 5:42b; Lk 6:34, 35c//Thomas 95:1-2; lend without return), Q 6:33 (Mt 5:47//Lk 6:33; not only to do good to those who can do good to you) and Q 6:36 (Mt 5:48//Lk 6:36; be compassionate to everybody as God is compassionate towards everybody). With regards to Jesus' critique on the temple's purity system, the parable inter alia parallels Jesus' sayings in Mark 7:14-15//Matthew 15:10-11//Thomas 14:5 (it is not what goes in that defiles, but what goes out). ${ }^{29}$ The parable, finally, iterates the kind of fictive family that makes up the kingdom. The kingdom consists of those who are like children (who had no status in 1stcentury Mediterranean world; Mk 10:13-16//Mt 19:13-15// Lk 18:15-17; see also Thom 22:2//Jn 3:3, 5), those who love their enemies (Q 6:27 [Mt 5:44a/ / Lk 6:27]) and not only those who love them (Q 6:32 [Mt 5:46/ / Lk 6:32]). Like the host, the kingdom belongs to those who do the will of God (Q 8:21 [Mt 12:50//Lk 8:21]//Thom 99:2).

The values in the parable are also paralleled in other Jesus parables, either in a positive or negative way. In the parables of the Mustard Seed (Q 13:18-19 [Mt 13:31-32//Lk 13:18-19]// Mk 4:30-32//Thom 20:1-4) and the Leaven (Q 13:20-21 [Mt 13:33/Lk 13:20-21]//Thom 96:1-2), the kingdom is respectively also described as consisting of 'unclean' weed and 'clean' seed and the 'impure'. In the parables of the Friend at Midnight (Lk 11:5-8; see Van Eck 2011a:1-14) and the Rich Man and Lazarus (Lk 16:19-26; see Van Eck 2009b:1-11), the neighbour and the rich man are criticised by Jesus for their lack of patronage in the form of general reciprocity. They should be like the host who invited those without status to his feast and the shepherd of the parable of the Lost Sheep (Lk 15:4-6; see Van Eck 2011b:1-10) who does his utmost so that everybody might have enough. In the parable of the Vineyard Labourers (Mt 20:1-5), we find the same status reversal as in the parable of the Feast.

Like the host in the parable, Jesus regularly associated with the so-called 'impure' and ate with the so-called 'sinners' of his day. Because of this, Jesus was called a glutton and drunkard and a friend of tax collectors and sinners (Lk 7:34). In the eyes of the dominant kingdoms of his time, Rome and the temple, Jesus had no honour and shame because of his eating practice and associations. He was a foolish patron who extended patronage to the wrong people and did not respect the boundaries of society - like the host in the parable.

29.See Funk et al. (1993:69): "The aphorism ... is a categorical challenge to the laws governing pollution and purity. Since the saying need not be taken entirely literally .. it can also be made to apply to other forms of pollution ...: it challenges the everyday, the inherited, the established, and erases social boundaries taken to be sacrosanct.'

\section{Acknowledgements Competing interests}

The author declares that he has no financial or personal relationship(s) which may have inappropriately influenced him in writing this article.

\section{References}

Abrahams, R.D., 1970, 'A performance-centred approach to gossip', Man 5(2), 290301. http://dx.doi.org/10.2307/2799654

Andreassen, R., 1998, 'Gossip in Henningsvær', Etnofoor 11(2), 41-56.

Arens, E., 1986, 'Ein Tischgespräch über Essen und (Ex)Kommunikation: Das Gleichnis vom Festmahl (Lk. 14, 16-24)', Kategetische Blätter 111, 449-452.

Arno, A., 1980, 'Fijian gossip as adjudication: A communication model of informal social control', Journal of Anthropological Research 36(3), 343-360.

Bailey, K.E, 1983, Poet and peasant and through peasant eyes: A literary-cultura approach to the parables of Jesus in Luke, William B. Eerdmans Publishing Company, Grand Rapids.

Bailey, K.E., 2008, Jesus through Middle Eastern eyes: Cultural studies in the gospels, IVP Academic, Downers Grove.

Boice, J.M., 1983, The parables of Jesus, Moody Press, Chicago.

Boucher, M.I., 1981, The parables, Michael Glazier Inc., Wilmington. (New Testament Message 7)

Braun, W., 1995, Feasting and social rhetoric in Luke 14, Cambridge University Press, Cambridge. (Society for New Testament Studies Monograph Series 85).

Brouwer, A.M., 1946, De gelijkenissen, A.W. Sijthoff's Uitgeversmaatschappij N.V., Leiden.

Bruce, A.B., 1886, The parabolic teaching of Christ: A systematic and critical study of the parables of our Lord, Hodder \& Stoughton, New York. PMid:20751561, PMCid:2257130

Bultmann, R., 1963, History of the synoptic tradition, Blackwell, Oxford.

Conzelmann, H., 1960, The theology of St. Luke, Harper \& Brothers, New York.

Crossan, J.D., 1973, In parables: The challenge of the historical Jesus, Harper \& Row, New York.

Crossan, J.D., 1991, The historical Jesus: The life of a Mediterranean Jewish peasant, HarperSanFrancisco, San Francisco. PMid:2064058

Daniels, J.W., 2008, 'Gossip's role in constituting Jesus as a shamanic figure in John's gospel', D.Theol thesis, Department of New-Testament Studies, Universtiy of South Africa.

Davie, G.J. (ed.), 1888, John Maldonatus - A commentary on the holy gospels: S. Matthew's gospel, transl. G.J. Davie, John Hodges, London.

Davies, W.D. \& Allison, D.C., 1997, A critical and exegetical commentary on the gospe according to Saint Matthew, vol. 3, T\&T Clark, Edinburgh. (International Critical Commentaries).

Derrett, J.D.M., 1976, Law in the New Testament, Darton, Longman, and Todd, London. Dibelius, M., 1971, From tradition to gospel, transl. B.L. Woolf, James Clarke, London.

Dillon, R.J., 1966, 'Towards a tradition-history of the parables of the true Israel (Matthew $21,33-22,14)^{\prime}$, Biblica 47, 1-42.

Dodd, C.H., 1961, The parables of the kingdom, Charles Scribner's Sons, New York. PMCid:1424126

Donahue, J.R., 1988, The gospel in parable: Metaphor, narrative and theology in the Synoptic gospels, Fortress Press, Philadelphia.

Douglas, M.T, 1975, Implicit meanings: Selected essays in anthropology, Routledge \& Kegan Paul, London.

Drury, J., 1985, The parables in the Gospels: History and allegory, Crossroads, New York.

Duling, D.C, 2012, A marginal scribe: Studies in the gospel of Matthew in a social-scientific perspective, Cascade Books, Eugene. (Matrix: The Bible in Mediterranean context).

Ferguson, E.F., 1987, Backgrounds of early Christianity, Eerdmans, Grand Rapids.

Fitzmyer, J.A., 1985, The gospel according to Luke X-XXIV, vol. II, Doubleday, New York.

Forbes, G.W., 2000, The God of old: The role of the Lukan parables in the purpose of Luke's gospel, Sheffield Academic, Sheffield. (Journal for the Study of the New Testament Supplementum 198)

Foster, G.M., 1967, 'Peasant society and the image of limited good', in J.M. Potter M.N. Diaz \& G.M. Forster (eds.), Peasant society: A reader, pp. 300-323, Little, Brown \& Co., Boston.

Funk, R.W., Hoover, R.W. \& The Jesus Seminar, 1993, The five gospels: The search for the authentic words of Jesus, Macmillan, New York.

Funk, R.W., Scott, B.B. \& Butts, J.R., 1988, The parables of Jesus: Red letter edition, The Jesus Seminar, Polebridge Press, Santa Rosa.

Gilmore, D.D., 1978, 'Varieties of gossip in a Spanish rural community', Ethnology 17(1), 89-99. http://dx.doi.org/10.2307/3773282

Gluckman, M., 1963, 'Gossip and scandal', Current Anthropology 4, 307-316. http:// dx.doi.org/10.1086/200378

Gnilka, J., 1993, Das Matthäusevangelium, vol. 2, 3rd edn., Herder, Freiburg. 
Goulder, M.D., 1974, Midrash and lection in Matthew, SPCK, London. PMid:4846137, PMCid:1611959

Groenewald, E.P., 1973, In gelykenisse het Hy geleer, N.G. Kerk-Uitgewers, Kaapstad. PMid:4541357

Gundry, R., 1982, Matthew: A commentary on his literary and theological art, William B. Eerdmans Publishing Company, Grand Rapids.

Hagner, D., 1995, Matthew, 2 vols., Word Books, Dallas. (World Biblical Commentary).

Hahn, F., 1970, 'Das Gleichnis von der Einladung zum Festmahl', in O. Bocher \& K. Haaker (eds.), Verborum veritas: Festschrift für Gustav Stählin, pp. 51-82, Brockhaus, Wuppertal.

Handelman, D., 1973, 'Gossip in encounters: The transmission of information in a bounded social setting', Man 8(2), 210-227. http://dx.doi.org/10.2307/2800847

Haviland, J.B., 1977, Gossip, reputation, and knowledge in Zinacantan, University of Chicago Press, Chicago. PMid:853139

Hendrickx, H., 1986, The parables of Jesus, Harper \& Row, San Francisco.

Hill, D., 1972, The gospel of Matthew, Oliphants, London.

Hultgren, A.J., 2000, The parables of Jesus: A commentary, William B. Eerdmans Publishing Company, Grand Rapids.

Hunter, A.M., 1971, The parables: Then \& now, SCM Press Ltd, London.

Hunter, A.M., 1976, Interpreting the parables, SCM Press Ltd, London.

Hunter, V., 1990, 'Gossip and the politics of reputation in classical Athens', Phoenix 44(4), 299-325. http://dx.doi.org/10.2307/1088805

Jeremias, J., 1972, The parables of Jesus, Charles Scribner's Sons, New York. PMid:4646494

Jones, I.H., 1995, The Matthean parables: A literary and historical commentary, E.J. Brill, Leiden. (Supplements to Novum Testamentum, vol. LXXX).

Keach, B., 1978, Exposition of the parables in the Bible, Kregel Publications, Grand Rapids.

Kilgallen, J.J., 2008, Twenty parables of Jesus in the gospel of Luke, Editrice Pontificio Instituto Biblico, Rome. (Subsidia Biblica 32).

Kim, C-H., 1975, 'The papyrus invitation', Journal of Biblical Literature 94, 391-402. http://dx.doi.org/10.2307/3265160

Kissinger, W.S., 1979, The parables of Jesus: A history of interpretation and bibliography, The Scarecrow Press, Metuchen.

Kistemaker, S.J., 1980, The parables: Understanding the stories Jesus told, Baker Books, Grand Rapids.

Klein, H., 1997, 'Botschaft für viele - Nachfolge von wenigen: Überlegungen zu Lk 14,15-35', Evangelische Theologie 57, 427-437.

Knapp, J.J., 1920, Gelijkenissen des Heeren, G.F. Callenbach, Nijkerk. PMid:16692517, PMCid:1318241

Linnemann, E., 1980, Parables of Jesus: Introduction and exposition, 5th edn., SPCK, London.

Lockyer, H., 1963, All the parables of the Bible, Zondervan, Grand Rapids. PMid:14067359

Louw, J.P. \& Nida, E.A. (eds.), 1988, Greek-English lexicon of the New Testament based on semantic domains, vol. 1: Domains, National Book Printers, Goodwood.

Luz, U., 1985, Das Evangelium nach Matthäus, vol. 3, Benziger Verlag, Zurich. (Evangelische Kritische Kommentar zum Neuen Testaments 1).

Malina, B.J., 1986, Christian origins and cultural anthropology: Practical models for biblical interpretation, John Knox Press, Atlanta.

Malina, B.J. \& Rohrbaugh, R.L., 1998, Social science commentary on the gospel of John, Fortress Press, Minneapolis.

Manson, T.W., 1951, The sayings of Jesus, Cambridge University Press, Cambridge.

Marshall, I.H., 1978, The gospel of Luke, Paternoster Press, Exeter.

McFague, S., 2002, Speaking in parables, SCM Press, London.

Morgan, G.C., 1953, The parables and metaphors of our Lord, Marshall, Morgan \& Scott, Ltd., London.

Neyrey, J.H., 1991, 'Ceremonies in Luke-Acts', in J.H. Neyrey (ed.), The social world of Luke-Acts: Models for interpretation, pp. 361-387, Hendrickson Publishers, Peabody.

Paine, R., 1967, 'What is gossip about? An alternative hypothesis', Man 2(2), 278-285. http://dx.doi.org/10.2307/2799493

Perkins, P., 1981, Hearing the parables of Jesus, Paulist Press, New York.

Perrin, N., 1967, Rediscovering the teaching of Jesus, Harper \& Row, New York. PMCid:1477491

Plummer, A., 1922, A critical and exegetical commentary on the gospel according to S., Luke, 5th edn., T \& T Clark, Edinburgh. (International Critical Commentaries).

Polag, A., 1979, Fragmenta Q: Textheft zur Logienquelle, Neukirchener Verlag, NeukirchenVluyn.

Reiser, M., 1997, Jesus and judgement: The eschatological proclamation in its Jewish context, transl. L. Maloney, Fortress Press, Minneapolis.

Rohrbaugh, R.L., 1991, 'The pre-industrial city in Luke-Acts: Urban social relations', in J.H. Neyrey (ed.), The social world of Luke-Acts: Models for interpretation, pp. 151-180, Hendrickson Publishers, Peabody.

Rohrbaugh, R.L., 2001, 'Gossip in the New Testament', in J.J. Pilch (ed.), Social scientific models for interpreting the Bible: Essays by the Context group in honour of Bruce J. Malina, pp. 239-259, Brill, Leiden. (Biblical Interpretation Series, vol. 53).
Sanders, J.A., 1974, 'The ethic of election in Luke's Great banquet parable', in J.L Crenshaw \& J.T. Willis (eds.), Essays in Old Testament ethics, pp. 245-271, Ktav, New York.

Schaff, P., 1890, Nicene and post-Nicene Fathers, ser. I, vol. 2, The Christian Literature Publishing Co., New York. (Christian Classic Ethereal Library).

Schippers, R., 1962, Gelijkenissen van Jezus, J.H. Kok N.V, Kampen. PMid:14467529

Schottroff, L., 1987, 'Das Gleichnis vom grossen Gastmahl in der Logionquelle', Evangelische Theologie 47, 192-211.

Schottroff, L., 2006, The parables of Jesus, transl. L.M. Maloney, Fortress Press, Minneapolis.

Schottroff, L., 2007, 'Von der Schwierigkeit zu teilen (Das Große Abendmahl) - Lk 14,12-24', in R. Zimmermann (ed.), Kompendium der Gleichnisse Jesu, pp. 593-603, Gütersloher Verlagshaus, München.

Schulz, S., 1973, Q: Die Spruchquelle der Evangelisten, Theologischer Verlag Zürich, Zürich.

Scott, B.B., 1989, Hear then the parable: A commentary on the parables of Jesus, Minneapolis, Fortress Press.

Scott, B.B., 2001, Re-imagine the world: An introduction to the parables of Jesus, Polebridge Press, Santa Rosa.

Smith, B.T.D., 1937, The parables of the synoptic Gospels: A critical study, Cambridge University Press, Cambridge.

Snodgrass, K.R., 2008, Stories with intent: A comprehensive guide to the parables of Jesus, William B. Eerdmans Publishing Company, Grand Rapids.

Spacks, P.M., 1985, Gossip, Knopf, New York.

Stein, R.H., 1981, An introduction to the parables of Jesus, The Westminster Press, Philadelphia.

Strack, H. \& Billerbeck, P., 1974, Kommentar zum Neuen Testament aus Talmud und Midrasch, Band 2, Das evangelium nach markus, Lukas und Johannes und die Apostelgeschichte, Beck, München.

Streeter, B.H., 1930, The four gospels: A study of origins, St. Martin's Press, New York.

Swartley, W.M., 1997, 'Unexpected banquet people', in V.G. Shillington (ed.), Jesus and his parables: Interpreting the parables of Jesus today, pp. 177-190, T\&T Clark, Edinburgh.

Timmer, J, 1990, The kingdom equation: A fresh look at the parables of Jesus, CRC Publications, Grand Rapids.

Trench, R.C., 1953, Notes on the parables of our Lord, Revell, Westwood. PMid:13101060

Taussig, H., 2009, In the beginning was the meal: Social experimentation \& early Christian identity, Fortress Press, Minneapolis.

Torrance, D.W. \& Torrance, T.F. (eds.), 1972, Calvin's commentaries: A harmony of the gospels of Matthew, and Luke, vol. 3, transl. A.W. Morrison, Saint Andrews Press, Edinburgh.

Van Eck, E., 2007, 'Die huwelik in die eerste-eeuse Mediterreense wêreld (II): Huwelik, egbreuk, egskeiding en hertrou', HTS Teologiese Studies/Theological Studies 63(1), 103-128. http://dx.doi.org/10.4102/hts.v63i1.205

Van Eck, E., 2008, 'Jesus en geweld: Markus 12:1-12 (en par) en Thomas 65', HTS Teologiese Studies/Theological Studies 64(4), 1735-1765. http://dx.doi.org/10.4102/ hts.v64i4.100

Van Eck, E., 2009a, 'Interpreting the parables of the Galilean Jesus: A social-scientific approach', HTS Teologiese Studies/Theological Studies 65(1), Art. \#308, 12 pages. approach', HTS Teologiese Studies/Theo
http://dx.doi.org/10.4102v65i1.308

Van Eck, E., 2009b, 'When patrons are not patrons: A social-scientific reading of the rich man and Lazarus (Lk 16:19-26)', HTS Teologiese Studies/Theological Studies 65(1), Art. \#309, 11 pages. http://dx.doi.org/10.4102/hts.v65i1.309

Van Eck, E., 2011a, 'When neighbours are not neighbours: A social-scientific reading of the parable of the friend at midnight (Lk 11:5-8)', HTS Teologiese Studies/Theological Studies 67(1), Art. \#788, 14 pages. http://dx.doi.org/10.4102/hts.v64i4.100

Van Eck, E., 2011b, 'In the kingdom everybody has enough - A social-scientific and realistic reading of the parable of the lost sheep (Lk 15:4-6)', HTS Teologiese Studies/Theological Studies 67(3), Art. \#1067, 10 pages. http://dx.doi.org/ 10.4102/ hts.v67i3.1067

Van Eck, E., 2012, 'Invitations and excuses that are not invitations and excuses: Gossip in Luke 14:18-20', HTS Teologiese Studies/Theological Studies 68(1), Art. \#1243, 10 pages. http://dx.doi.org/10.4102/hts. v68i1.1243

Via, D.O., 1967, The parables: Their literary and existential dimension, Fortress Press, Philadelphia.

Vögtle, A., 1996, Gott and seine Gäste: Das Schicksal des Gleichnisse Jesu vom grossen Gastmahl, Neukirchen-Vluyn, Neukirchener. (Biblische-theologische Studien).

Weder, H., 1978, Die Gleichnisse Jesu als Metaphern: Traditions- und redaktionsgeschichtliche Analysen und Interpretationen, Vandenhoeck \& Ruprecht, Göttingen. (FRLANT 120).

Weiser, A., 1971, Die Knechtgleichnisse der synoptischen Evangelien, Kösel-Verlag, Munich. (SANT 29).

Wenham, D., 1989, The parables of Jesus: Pictures of a revolution, Hodder \& Stoughton, London. (The Jesus Library.) PMCid:2498874

Yerkovich, S., 1977, 'Gossiping as a way of speaking', Journal of Communication 27(1), 192-197. http://dx.doi.org/10.1111/j.1460-2466.1977.tb01817.x

Young, B.H., 1989, Jesus and his Jewish parables: Rediscovering the roots of Jesus' teaching, Paulist Press, New York. 